\title{
Lactation Performance by Dairy Cows Fed Supplemental Biotin and a B-Vitamin Blend
}

\author{
D. N. Majee, ${ }^{\star}$ E. C. Schwab, ${ }^{\star}$ S. J. Bertics, ${ }^{*}$ W. M. Seymour,† and R. D. Shaver* \\ *Department of Dairy Science, University of Wisconsin, Madison 53706 \\ †Roche Vitamins Inc., Parsippany, NJ 07054
}

\begin{abstract}
The objective of Trial 1 was to evaluate in dairy cows the effects of dietary supplementation with biotin and a B-vitamin blend on dry matter intake (DMI), milk yield, composition and component yields, total tract nutrient digestion, and plasma metabolites. Twenty-four multiparous Holstein cows averaging $46 \pm 8 \mathrm{~d}$ in milk at trial initiation were randomly assigned to treatments in a replicated $4 \times 4$ Latin square design with $28 \mathrm{~d}$ periods. The four treatments were: 1) a control diet (C) with no supplemental B-vitamins; 2) C plus supplemental biotin at $20 \mathrm{mg} / \mathrm{d}$ (B); 3) C plus supplemental thiamin $(150 \mathrm{mg} / \mathrm{d})$, riboflavin $(150 \mathrm{mg} / \mathrm{d})$, pyridoxine $(120 \mathrm{mg} /$ d), $B_{12}(0.5 \mathrm{mg} / \mathrm{d})$, niacin $(3000 \mathrm{mg} / \mathrm{d})$, pantothenic acid $(475 \mathrm{mg} / \mathrm{d})$, folic acid $(100 \mathrm{mg} / \mathrm{d})$, and biotin $(20 \mathrm{mg} / \mathrm{d})$ (BBVIT1X); 4) C plus supplemental thiamin (300 mg/ d), riboflavin (300 $\mathrm{mg} / \mathrm{d})$, pyridoxine $(240 \mathrm{mg} / \mathrm{d}), \mathrm{B}_{12}(1.0$ $\mathrm{mg} / \mathrm{d})$, niacin $(6000 \mathrm{mg} / \mathrm{d})$, pantothenic acid $(950 \mathrm{mg} / \mathrm{d})$, folic acid (200 mg/d), and biotin (40 mg/d) (BBVIT2X). Intake of DM was increased $0.7 \mathrm{~kg} / \mathrm{d}$ for $\mathrm{B}$ vs. $\mathrm{C}$ and BBVIT1X and $1.3 \mathrm{~kg} / \mathrm{d}$ for B vs. BBVIT2X. Milk yield was increased $1.7 \mathrm{~kg} / \mathrm{d}$ for B vs. C. For BBVIT1X, milk yield was similar to B and BBVIT2X and tended to be higher than C. Yields of milk protein and lactose but not fat were higher for B than C. For BBVIT1X, milk component yields were similar to $\mathrm{B}$ and tended to be higher than $\mathrm{C}$, with the exception of lactose yield where BBVIT1X was higher than C. The objective of Trial 2 was to evaluate DMI and milk yield, composition and component yields by dairy cows fed diets supplemented with either $40 \mathrm{mg} / \mathrm{d}$ biotin or the B-vitamin blend (BBVIT1X) compared to cows supplemented with 20 $\mathrm{mg} / \mathrm{d}$ dietary biotin. Neither the $40 \mathrm{mg} / \mathrm{d}$ biotin treatment nor the B-vitamin blend enhanced lactation performance over the $20 \mathrm{mg} / \mathrm{d}$ biotin treatment. Biotin efficacy in short-term trials suggests that biotin may improve milk yield directly via effects on intake and (or) nutrient metabolism rather than indirectly via im-
\end{abstract}

Received August 17, 2002.

Accepted February 2, 2003.

Corresponding author: R. D. Shaver; email: rdshaver@facstaff. wisc.edu. proved hoof health. More research is needed to determine the mode of action for supplemental dietary biotin. (Key words: biotin, B-vitamins, dairy cows, milk production)

Abbreviation key: $\mathbf{B}=$ Biotin at $1 \mathrm{X}$ dose in Trial 1 , $\mathbf{B} 1 \mathbf{X}=$ Biotin at $1 \mathrm{X}$ dose in Trial $2, \mathbf{B 2 X}=$ Biotin at $2 \mathrm{X}$ dose in Trial 2, BBVIT1X = Biotin and B-vitamin blend at $1 \mathrm{X}$ dose in Trials 1 and $2, \mathbf{B B V I T 2 X}=$ Biotin and $\mathrm{B}$-vitamin blend at $2 \mathrm{X}$ dose in Trial $1, \mathbf{C}=$ Control in Trial 1.

\section{INTRODUCTION}

The Dairy NRC (2001) does not provide recommended B-vitamin allowances for lactating dairy cows because of a lack of research on B-vitamin requirements for gestation, health, and milk production. Also, it was felt that, in general, B-vitamin requirements could be met through synthesis by ruminal microorganisms and escape of basal dietary sources from the rumen.

However, recent evidence of improved lactation performance from B-vitamin supplementation can be found in the literature. Supplemental dietary thiamin (150 to $300 \mathrm{mg} / \mathrm{d}$ ) increased milk and component yields by cows fed low NDF, high NSC diets (Shaver and Bal, 2000). Supplemental dietary folic acid (1.3 to $2.5 \mathrm{~g} / \mathrm{d}$ ) increased milk yield in multiparous but not primiparous cows (Girard and Matte, 1998). Girard and Matte (1997) reported a numerical increase $(P>0.10)$ in milk production in response to vitamin $B_{12}$ injections $(10 \mathrm{mg} /$ wk, i.m.) in primiparous cows. Because of extensive ruminal degradation of choline (Sharma and Erdman, 1988) and positive milk yield and fat test responses to choline supplemented in a ruminally-protected form (Erdman, 1994), ruminally-protected choline products are available commercially. Supplemental dietary biotin $(20 \mathrm{mg} / \mathrm{d})$ improved hoof health and DHI-estimated milk yield (Midla et al., 1998). Milk yield increased linearly with 0,10 , and $20 \mathrm{mg} / \mathrm{d}$ biotin supplemented in diets from $14 \mathrm{~d}$ prepartum through $100 \mathrm{~d}$ postpartum (Zimmerly and Weiss, 2001). Although niacin is a widely used supplemental B-vitamin by the feed indus- 
try, the Dairy NRC (2001) concluded from a summary of 25 trials that the routine use of niacin to enhance lactation performance by dairy cows or to minimize the risk of ketosis and fatty liver is not recommended.

The objective of Trial 1 was to evaluate in dairy cows the effects of dietary supplementation with biotin and a B-vitamin blend on DMI, milk yield, composition and component yields, total tract nutrient digestion, and plasma metabolites. The objective of Trial 2 was to evaluate DMI and milk yield, composition and component yields by dairy cows fed diets supplemented with 40 $\mathrm{mg} / \mathrm{d}$ biotin or the B-vitamin blend compared to cows fed the $20 \mathrm{mg} / \mathrm{d}$ biotin dose tested in Trial 1.

\section{MATERIALS AND METHODS}

\section{Trial 1}

The Research Animal and Resource Center of the College of Agriculture and Life Sciences at the University of Wisconsin-Madison approved the experimental protocol. Twenty-four multiparous Holstein cows were randomly assigned to treatments in a replicated $4 \times 4$ Latin square design with $28 \mathrm{~d}$ periods. Cows were housed and fed in tie-stalls. The first $14 \mathrm{~d}$ of each period were for diet adaptation and sampling occurred on $d$ 15 through 28 . Cows averaged $46 \pm 8 \mathrm{DIM}$ at trial initiation and were injected with bovine somatotropin (Posilac, Monsanto Company, St. Louis, MO) every $14 \mathrm{~d}$ starting on $d 1$ of the experiment. The four treatments were: 1) control diet (C) with no supplemental B-vitamins; 2) C plus supplemental biotin at $20 \mathrm{mg} / \mathrm{d}$ (Rovimix $\mathrm{H}-2$ spray-dried 2\%) (B); 3) C plus supplemental thiamin $\left(150 \mathrm{mg} / \mathrm{d}\right.$; Rovimix $\mathrm{B}_{1}$ fine-crystalline powder $92 \%)$, riboflavin $\left(150 \mathrm{mg} / \mathrm{d}\right.$; Rovimix $\mathrm{B}_{2}$ spray-dried $80 \%)$, pyridoxine $\left(120 \mathrm{mg} / \mathrm{d}\right.$; Rovimix $\mathrm{B}_{6}$ fine-crystalline powder $82 \%), \mathrm{B}_{12}\left(0.5 \mathrm{mg} / \mathrm{d} ; \mathrm{B}_{12}\right.$ crystalline powder $1 \%$ dilution), niacin (3000 mg/d; Rovimix niacin fine-crystalline powder $99.5 \%$ ), pantothenic acid ( $475 \mathrm{mg} / \mathrm{d}$; Rovimix Calpan spray-dried 92\%), folic acid (100 mg/d; Rovimix Folic spray-dried 80\%), and biotin ( $20 \mathrm{mg} / \mathrm{d}$; Rovimix H-2 spray-dried 2\%) (BBVIT1X); 4) C plus supplemental thiamin $\left(300 \mathrm{mg} / \mathrm{d}\right.$; Rovimix $\mathrm{B}_{1}$ fine-crystalline powder $92 \%)$, riboflavin $\left(300 \mathrm{mg} / \mathrm{d}\right.$; Rovimix $\mathrm{B}_{2}$ spray-dried $80 \%)$, pyridoxine $\left(240 \mathrm{mg} / \mathrm{d}\right.$; Rovimix $\mathrm{B}_{6}$ fine-crystalline powder $82 \%), \mathrm{B}_{12}\left(1.0 \mathrm{mg} / \mathrm{d} ; \mathrm{B}_{12}\right.$ crystalline powder $1 \%$ dilution), niacin $(6000 \mathrm{mg} / \mathrm{d}$; Rovimix Niacin fine-crystalline powder 99.5\%), pantothenic acid (950 mg/d; Rovimix Calpan spray-dried 92\%), folic acid (200 mg/d; Rovimix Folic spray-dried 80\%), and biotin (40 mg/d; Rovimix H-2 spray-dried 2\%) (BBVIT2X). Average daily intakes of supplemental B-vitamins calculated from premix formulations and actual DMI are presented in Table 1. Control and treatment premixes were included in the respective TMR at $0.46 \%$ of DM for average daily premix intakes of $115 \mathrm{~g} / \mathrm{d}$. The four mo supply of premixes needed for the trial were prepared immediately prior to the start of the trial by Roche Vitamins, Inc. (Parsippany, NJ) at their Blend Plant in Ames, IA. Shurson et al. (1996) reported average monthly losses of B-vitamin potency after four mo in storage ranging from 0 to $8 \%$ across the B-vitamins in a vitamin premix containing choline chloride, which increases the breakdown of B-vitamins; choline chloride was not a premix ingredient in our study. Midla et al. (1998) found no loss of B-vitamin potency $24 \mathrm{~h}$ after mixing in a TMR. The formulation target levels for biotin in treatment $\mathrm{B}$ and $\mathrm{B}_{12}$, biotin, folic acid, and niacin in BBVIT1X were obtained from Roche guidelines for ruminants (Roche, 2000). The formulation target level for thiamin in BBVIT1X was based on Shaver and Bal (2000). The formulation target levels for pantothenic acid, pyridoxine, and riboflavin in BBVIT1X were based on Roche guidelines for lactating sows (NRC, 1988) extrapolated to lactating dairy cows according to BW and feed intake differences (Roche, 2000). The lower end of the range of Roche B-vitamin guidelines for ruminants and sows (Roche, 2000) was used to develop formulation target levels for BBVIT1X, because of cost considerations for the B-vitamin blend. The BBVIT2X treatment was included to allow for a dose-response comparison.

Cows were fed ad libitum twice per $\mathrm{d}$ and the amounts of TMR offered and refused were recorded daily to maintain refusals at approximately $10 \%$. The TMR was comprised of $50 \%$ alfalfa silage and $50 \%$ of a concentrate mix (DM basis) that contained ground shelled corn, expeller-processed soybean meal, and animal fat to formulate diets to meet or exceed NRC (2001) $\mathrm{NE}_{\mathrm{L}}, \mathrm{CP}$, RUP, macro- and micro-mineral, and vitamin A, D, and E allowances (Table 2). Alfalfa silage was used as the sole forage in the diets, because corn silage was not available when the study was initiated. Cows were milked twice daily with production recorded at each milking. Milk samples taken at a.m. and p.m. milkings on three consecutive days during wk 3 and 4 were analyzed for milk fat, true protein, lactose, and urea $\mathrm{N}$ (AgSource Milk Analysis Laboratory, Menomonie, WI) by infrared analysis (AOAC, 1997) with a Fossmatic605 utilizing a B filter (Foss Electric, Hillerød, Denmark). Milk composition was calculated as an average of the a.m and p.m. samples with the proportion of daily milk production at that milking used as a weighting factor. All cows were weighed for three consecutive $d$ at the start of the trial and on d 26 to 28 of each period.

The alfalfa silage DM content was determined weekly using a microwave oven to allow for adjustment of the 
Table 1. Average daily intakes of supplemental B-vitamins calculated from premix formulations and actual DMI for Trials $1^{1}$ and $2^{2}$.

\begin{tabular}{llllcllr}
\hline & Trial 1 & Trial 1 & Trial 1 & Trial 1 & Trial 2 & Trial 2 & Trial 2 \\
B-vitamin $(\mathrm{mg} / \mathrm{d})^{3}$ & $\mathrm{C}$ & $\mathrm{B}$ & BBVIT1X & BBVIT2X & B1X & B2X & BBVIT1X \\
\hline Biotin & 0 & 21 & 20 & 40 & 21 & 41 & 21 \\
Folic acid & 0 & 0 & 102 & 199 & 0 & 0 & 105 \\
Niacin & 0 & 0 & 3056 & 5965 & 0 & 0 & 3156 \\
Pantothenic acid & 0 & 0 & 484 & 945 & 0 & 0 & 500 \\
Pyridoxine & 0 & 0 & 122 & 239 & 0 & 0 & 126 \\
Riboflavin & 0 & 0 & 153 & 298 & 0 & 0 & 158 \\
Thiamin & 0 & 0 & 153 & 298 & 0 & 0 & 158 \\
Vitamin $\mathrm{B}_{12}$ & 0 & 0 & 0.51 & 0.98 & 0 & 0 & 0.53 \\
\hline
\end{tabular}

${ }^{1} \mathrm{C}=$ control diet with no supplemental B-vitamins; $\mathrm{B}=$ supplemental biotin at $20 \mathrm{mg} / \mathrm{d}$ (Rovimix H-2 spray-dried 2\%); BBVIT1X = supplemental thiamin $\left(150 \mathrm{mg} / \mathrm{d}\right.$; Rovimix $\mathrm{B}_{1}$ fine-crystalline powder $\left.92 \%\right)$, riboflavin ( $150 \mathrm{mg} / \mathrm{d}$; Rovimix $\mathrm{B}_{2}$ spray-dried $\left.80 \%\right)$, pyridoxine $\left(120 \mathrm{mg} / \mathrm{d}\right.$; Rovimix $\mathrm{B}_{6}$ fine-crystalline powder $82 \%), \mathrm{B}_{12}\left(0.5 \mathrm{mg} / \mathrm{d} ; \mathrm{B}_{12}\right.$ crystalline powder $1 \%$ dilution), niacin $(3000 \mathrm{mg} / \mathrm{d}$; Rovimix niacin fine-crystalline powder 99.5\%), pantothenic acid (475 mg/d; Rovimix Calpan spray-dried 92\%), folic acid (100 mg/d; Rovimix Folic spray-dried $80 \%)$, and biotin (20 mg/d; Rovimix H-2 spray-dried 2\%); BBVIT2X = supplemental thiamin $\left(300 \mathrm{mg} / \mathrm{d}\right.$; Rovimix $\mathrm{B}_{1}$ fine-crystalline powder $\left.92 \%\right)$, riboflavin $\left(300 \mathrm{mg} / \mathrm{d}\right.$; Rovimix $\mathrm{B}_{2}$ spray-dried $\left.80 \%\right)$, pyridoxine $\left(240 \mathrm{mg} / \mathrm{d}\right.$; Rovimix $\mathrm{B}_{6}$ fine-crystalline powder $\left.82 \%\right), \mathrm{B}_{12}\left(1.0 \mathrm{mg} / \mathrm{d} ; \mathrm{B}_{12}\right.$ crystalline powder $1 \%$ dilution), niacin $(6000 \mathrm{mg} / \mathrm{d}$; Rovimix Niacin fine-crystalline powder $99.5 \%)$, pantothenic acid $(950 \mathrm{mg} / \mathrm{d}$; Rovimix Calpan spray-dried 92\%), folic acid (200 mg/d; Rovimix Folic spray-dried 80\%), and biotin (40 mg/ d; Rovimix H-2 spray-dried $2 \%$ ).

${ }^{2} \mathrm{~B} 1 \mathrm{X}=$ supplemental biotin at $20 \mathrm{mg} / \mathrm{d}$ (Rovimix $\mathrm{H}-2$ spray-dried $2 \%$ ); $\mathrm{B} 2 \mathrm{X}=$ supplemental biotin at 40 $\mathrm{mg} / \mathrm{d}$ (Rovimix H-2 spray-dried 2\%); BBVIT1X = supplemental thiamin $\left(150 \mathrm{mg} / \mathrm{d}\right.$; Rovimix $\mathrm{B}_{1}$ fine-crystalline powder $92 \%$ ), riboflavin $\left(150 \mathrm{mg} / \mathrm{d}\right.$; Rovimix $\mathrm{B}_{2}$ spray-dried $\left.80 \%\right)$, pyridoxine $\left(120 \mathrm{mg} / \mathrm{d}\right.$; Rovimix $\mathrm{B}_{6}$ finecrystalline powder $82 \%), \mathrm{B}_{12}\left(0.5 \mathrm{mg} / \mathrm{d} ; \mathrm{B}_{12}\right.$ crystalline powder $1 \%$ dilution), niacin $(3000 \mathrm{mg} / \mathrm{d}$; Rovimix niacin fine-crystalline powder 99.5\%), pantothenic acid (475 mg/d; Rovimix Calpan spray-dried 92\%), folic acid (100 mg/d; Rovimix Folic spray-dried 80\%), and biotin $(20 \mathrm{mg} / \mathrm{d}$; Rovimix H-2 spray-dried $2 \%)$.

${ }^{3}$ Provided in rice byproduct-calcite grits $(38 \% \mathrm{Ca}$ )-mineral oil ( $1 \%$ of blend) premixes that were included in respective TMR at $0.46 \%$ of $\mathrm{DM}$.

as-fed ratios of dietary ingredients. The alfalfa silage and concentrate mixture were sampled during wk 3 and 4 of each period and composited by period for nutrient analyses. The premixes were sampled during wk 3 and 4 of each period and composited by period for quality control evaluation by Roche Vitamins, Inc. (Parsippany, $\mathrm{NJ}$ ). Total tract nutrient (DM, OM, and NDF) digestibilities were determined using lignin as an internal marker; fecal grab samples were collected at 8-hr intervals over the last $3 \mathrm{~d}$ of each period. Ort samples were collected for each cow on the last $3 \mathrm{~d}$ of each period. Feed, ort, and fecal samples were dried for $48 \mathrm{~h}$ in a $55^{\circ} \mathrm{C}$ forced-air oven to determine $\mathrm{DM}$ content and then ground to pass a $1 \mathrm{~mm}$ Wiley mill screen (Arthur $\mathrm{H}$. Thomas, Philadelphia, PA). Ort and fecal samples were composited by cow and period. Feed composites were analyzed in duplicate at Dairyland Laboratories (Arcadia, WI) for OM (AOAC, 1997), CP (AOAC, 1997) using a LECO-428 combustion analyzer (LECO Corp., St. Joseph, MI), NDF using $\alpha$-amylase and sodium sulfite (Van Soest et al., 1991), ether extract (AOAC, 1997), starch using a YSI-2700 Biochemistry Analyzer (Yellow Springs Instrument, Inc., Yellow Springs, OH) after enzymatic hydrolysis, and $\mathrm{ADF}$ and lignin (AOAC, 1997). Feed samples were not analyzed for B-vitamin concentrations, because ruminal microbial synthesis of $\mathrm{B}$-vitamins is the primary factor influencing post-rumi- nal supply of B-vitamins with unsupplemented diets (Zinn et al., 1987). Ort and fecal composites were analyzed in duplicate at Dairyland Laboratories (Arcadia, WI) for OM, NDF, and lignin as described. Blood samples were obtained four $\mathrm{h}$ after feeding on two consecutive days during wk 3 and 4 of each period for determination of plasma glucose, BHBA, and NEFA as described by Hayirli et al. (2002). Data were analyzed by the MIXED procedure of SAS/STAT (1999) for a replicated Latin square design. All mean comparisons were by the PDIFF method of SAS/STAT (1999) after a significant $(P<0.05)$ treatment effect.

\section{Trial 2}

The conduct of Trial 2 was similar to that of Trial 1 and only the differences between the two trials are presented. Twenty-four multiparous Holstein cows (84 \pm 15 DIM at trial initiation) were randomly assigned to treatments in a replicated $3 \times 3$ Latin square design with $28 \mathrm{~d}$ periods. The three treatments were: 1 ) diet formulated to provide supplemental biotin at $20 \mathrm{mg} /$ $\mathrm{hd} / \mathrm{d}$ (Rovimix H-2 spray-dried 2\%) (B1X); 2) same diet as B1X formulated to provide supplemental biotin at $40 \mathrm{mg} / \mathrm{hd} / \mathrm{d}$ (Rovimix H-2 spray-dried 2\%) (B2X); 3) same diet as B1X formulated to provide supplemental thiamin $\left(150 \mathrm{mg} / \mathrm{d}\right.$; Rovimix $\mathrm{B}_{1}$ fine-crystalline powder 
Table 2. Dietary ingredients and nutrient composition for Trials 1 and 2.

\begin{tabular}{lcc}
\hline Item & Trial 1 & Trial 2 \\
\hline Ingredient, \% of DM & & \\
Alfalfa silage & \\
Ground shelled corn & 50.0 & 50.0 \\
Soybean hulls & 29.6 & 29.6 \\
Tallow & 9.8 & 9.8 \\
Soybean meal, expeller & 0.9 & 0.9 \\
Calcium carbonate & 6.7 & 6.7 \\
Dicalcium phosphate & 0.55 & 0.55 \\
Magnesium oxide & 0.54 & 0.54 \\
Sodium bicarbonate & 0.22 & 0.22 \\
Trace-mineralized salt & 0.64 & 0.64 \\
Vitamin A-D-E premix & 0.46 \\
B-vitamin premix & 0.46 & 0.18 \\
Nutrient, \% of DM & 0.18 & 0.46 \\
CP & 0.46 & \\
NDF & 18.8 & 19.0 \\
ADF & 34.3 & 32.0 \\
Ether extract & 25.5 & 26.1 \\
NFC & 4.1 & 5.1 \\
Starch & 32.6 & 22.9 \\
\hline
\end{tabular}

1Trial 1: Averaged $21.3 \% \mathrm{CP}$ and $39.2 \% \mathrm{NDF}$ (DM basis) and $34.6 \%$ DM.

Trial 2: Averaged $24.3 \% \mathrm{CP}$ and $43.5 \% \mathrm{NDF}$ (DM basis) and $30.2 \%$ DM.

${ }^{2}$ Soy Plus, West Central Soy, Ralston, IA.

${ }^{3} 0.55 \% \mathrm{Mn}, 0.55 \% \mathrm{Zn}, 0.35 \% \mathrm{Fe}, 0.14 \% \mathrm{Cu}, 0.0008 \% \mathrm{I}, 0.006 \% \mathrm{Se}$, and $0.002 \%$ Co from inorganic sources.

${ }^{4} 3308 \mathrm{IU}$ of vitamin $\mathrm{A} / \mathrm{g}, 1103 \mathrm{IU}$ of vitamin $\mathrm{D} / \mathrm{g}$, and $11.03 \mathrm{IU}$ of vitamin $\mathrm{E} / \mathrm{g}$.

${ }^{5} \mathrm{NFC}=$ Nonfiber carbohydrate $=100-\mathrm{NDF}-\mathrm{CP}$-ether extract-Ash.

92\%), riboflavin (150 mg/d; Rovimix $\mathrm{B}_{2}$ spray-dried $80 \%$ ), pyridoxine $\left(120 \mathrm{mg} / \mathrm{d}\right.$; Rovimix $\mathrm{B}_{6}$ fine-crystalline powder $82 \%), \mathrm{B}_{12}\left(0.5 \mathrm{mg} / \mathrm{d} ; \mathrm{B}_{12}\right.$ crystalline powder $1 \%$ dilution), niacin ( $3000 \mathrm{mg} / \mathrm{d}$; Rovimix niacin fine-crystalline powder $99.5 \%$ ), pantothenic acid ( $475 \mathrm{mg} / \mathrm{d}$; Rovimix Calpan spray-dried 92\%), folic acid (100 mg/d; Rovimix Folic spray-dried 80\%), and biotin $(20 \mathrm{mg} / \mathrm{d}$; Rovimix H-2 spray-dried 2\%) (BBVIT1X). Average daily intakes of supplemental B-vitamins calculated from premix formulations and actual DMI are presented in Table 1. The TMR composition is presented in Table 2.

\section{RESULTS AND DISCUSSION}

Dietary nutrient composition and lactation performance data for both trials are presented in Tables 2 and 3, respectively. Digestibility and plasma data for Trial 1 are presented in Table 4.

\section{Trial 1}

Body weights were not different $(P>0.10)$ among the treatments and averaged $662 \mathrm{~kg}$. Intake of DM was increased $(P<0.05) 0.7 \mathrm{~kg} / \mathrm{d}$ for B vs. C and BBVIT1X and $1.3 \mathrm{~kg} / \mathrm{d}$ for B vs. BBVIT2X. Zimmerly and Weiss
(2001) evaluated 0,10 , and $20 \mathrm{mg} / \mathrm{d}$ supplemental dietary biotin, and DMI was not different across treatments during the first 100 DIM. Margerison et al. (2002) reported a lack of DMI response to $20 \mathrm{mg} / \mathrm{d}$ supplemental dietary biotin during the first 120 DIM. The main differences between these two studies and our study were: continuous lactation vs. Latin-square design, cows evaluated from 0 to 100 to 120 DIM vs. $46 \pm 8$ to $158 \pm 8 \mathrm{DIM}$, and mixed forage program with corn silage vs. all alfalfa silage. How these factors may be related to the different intake response to dietary biotin supplementation between trials is unclear.

Milk yield was increased $(P<0.05) 1.7 \mathrm{~kg} / \mathrm{d}$ for B vs. C. It cannot be determined from this study whether the increase in milk yield was in response to the higher DMI or vice versa. Zimmerly and Weiss (2001) reported that milk yield increased $0.9 \mathrm{~kg} / \mathrm{d}$ and $2.8 \mathrm{~kg} / \mathrm{d}$ linearly above control (no supplemental biotin) for 10 and 20 $\mathrm{mg} / \mathrm{d}$ supplemental dietary biotin, respectively, during the first 100 DIM with no statistical change in DMI. Margerison et al. (2002) reported that milk yield was increased $2.0 \mathrm{~kg} / \mathrm{d}$ above control (no supplemental biotin) by $20 \mathrm{mg} / \mathrm{d}$ supplemental dietary biotin during the first 120 DIM. For BBVIT1X, milk yield was similar $(P$ $>0.10$ ) to B and BBVIT2X (38.3 vs. 38.9 and $37.5 \mathrm{~kg} /$ $\mathrm{d}$, respectively) and tended $(P<0.10)$ to be higher than C ( 38.3 vs. $37.2 \mathrm{~kg} / \mathrm{d})$. Milk yield was similar $(P>0.10)$ for C and BBVIT2X. Feed efficiency ( $\mathrm{kg}$ milk/kg DMI) was similar $(P>0.10)$ across treatments and averaged 1.53 (data not presented in table).

Yields of milk protein and lactose but not fat were higher $(P<0.05)$ for B than C. Zimmerly and Weiss (2001) reported that yield of milk protein but not fat was increased for biotin-supplemented vs. unsupplemented cows. For BBVIT1X, milk component yields were similar $(P>0.10)$ to $\mathrm{B}$ and tended $(P<0.10)$ to be higher than $C$, with the exception of lactose yield where BBVIT1X was higher than $\mathrm{C}(P<0.05)$. Yields of milk fat and lactose but not protein were lower $(P<0.05)$ for BBVIT2X than BBVIT1X. Milk composition was not different across treatments $(P>0.10)$ except for lactose percentage where B and BBVIT1X were higher $(P<$ 0.05 ) than C and BBVIT2X. Milk fat and protein percentages were unaffected by dietary biotin supplementation in the studies of Margerison et al. (2002) and Zimmerly and Weiss (2001). In the present experiment lactose yield of cows supplemented with $20 \mathrm{mg} / \mathrm{d}$ dietary biotin was increased by $110 \mathrm{~g} / \mathrm{d}$ compared to the control. This increase in lactose yield is equivalent to $220 \mathrm{~g} / \mathrm{d}$ of glucose. Biotin is a required co-factor for enzymes involved in propionate utilization and gluconeogenesis (McDowell, 2000). Supplemental biotin may have alleviated a limitation on the activities of these enzymes leading to increased lactose synthesis. We can provide 
Table 3. Impact of dietary supplementation with Biotin and a B-vitamin blend on BW, DMI, and milk production and composition for Trials $1^{1}$ and $2^{2}$.

\begin{tabular}{|c|c|c|c|c|c|c|c|c|c|}
\hline Item & $\begin{array}{l}\text { Trial } 1 \\
\mathrm{C}\end{array}$ & $\begin{array}{l}\text { Trial } 1 \\
\text { B }\end{array}$ & $\begin{array}{l}\text { Trial } 1 \\
\text { BBVIT1X }\end{array}$ & $\begin{array}{l}\text { Trial } 1 \\
\text { BBVIT2X }\end{array}$ & SE & $\begin{array}{l}\text { Trial } 2 \\
\text { B1X }\end{array}$ & $\begin{array}{l}\text { Trial } 2 \\
\text { B2X }\end{array}$ & $\begin{array}{l}\text { Trial } 2 \\
\text { BBVIT1X }\end{array}$ & $\mathrm{SE}$ \\
\hline BW, kg & 662 & 664 & 660 & 663 & 4 & 670 & 675 & 676 & 4 \\
\hline DMI, $\mathrm{kg} / \mathrm{d}$ & $25.0^{\mathrm{b}}$ & $25.7^{\mathrm{a}}$ & $25.0^{\mathrm{b}}$ & $24.4^{\mathrm{b}}$ & 0.4 & 25.4 & 25.7 & 26.3 & 0.6 \\
\hline \multicolumn{10}{|l|}{ Production, kg/d } \\
\hline Milk & $37.2^{\mathrm{b}}$ & $38.9^{\mathrm{a}}$ & $38.3^{\mathrm{ab}}$ & $37.5^{\mathrm{b}}$ & 0.8 & 41.1 & 40.8 & 41.1 & 0.7 \\
\hline Fat & $1.23^{\mathrm{ab}}$ & $1.25^{\mathrm{a}}$ & $1.25^{\mathrm{a}}$ & $1.19^{\mathrm{b}}$ & 0.03 & 1.39 & 1.39 & 1.40 & 0.03 \\
\hline Protein & $1.09^{\mathrm{b}}$ & $1.15^{\mathrm{a}}$ & $1.13^{\mathrm{ab}}$ & $1.11^{\mathrm{b}}$ & 0.02 & 1.15 & 1.14 & 1.16 & 0.02 \\
\hline Lactose & $1.79^{\mathrm{b}}$ & $1.90^{\mathrm{a}}$ & $1.87^{\mathrm{a}}$ & $1.81^{\mathrm{b}}$ & 0.05 & 1.98 & 1.97 & 1.99 & 0.06 \\
\hline \multicolumn{10}{|c|}{ Milk Composition } \\
\hline Fat, \% & 3.34 & 3.24 & 3.28 & 3.20 & 0.07 & 3.40 & 3.40 & 3.43 & 0.06 \\
\hline Protein, \% & 2.95 & 2.97 & 2.96 & 2.96 & 0.02 & 2.80 & 2.79 & 2.83 & 0.02 \\
\hline Lactose, \% & $4.81^{\mathrm{b}}$ & $4.87^{\mathrm{a}}$ & $4.88^{\mathrm{a}}$ & $4.82^{\mathrm{b}}$ & 0.04 & 4.83 & 4.83 & 4.84 & 0.04 \\
\hline MUN, mg/dl & 12.2 & 12.6 & 12.7 & 12.8 & 0.4 & 13.0 & 13.2 & 13.2 & 0.4 \\
\hline
\end{tabular}

${ }^{\mathrm{a}, \mathrm{b}}$ Means within the same row within a trial with different superscripts differ $(P<0.05)$.

${ }^{1} \mathrm{C}=$ control diet with no supplemental B-vitamins; $\mathrm{B}=$ supplemental biotin at $20 \mathrm{mg} / \mathrm{d}$ (Rovimix H-2 spray-dried 2\%); BBVIT1X = supplemental thiamin $\left(150 \mathrm{mg} / \mathrm{d}\right.$; Rovimix $\mathrm{B}_{1}$ fine-crystalline powder $\left.92 \%\right)$, riboflavin ( $150 \mathrm{mg} / \mathrm{d}$; Rovimix $\mathrm{B}_{2}$ spray-dried $\left.80 \%\right)$, pyridoxine $\left(120 \mathrm{mg} / \mathrm{d}\right.$; Rovimix $\mathrm{B}_{6}$ fine-crystalline powder $82 \%), \mathrm{B}_{12}\left(0.5 \mathrm{mg} / \mathrm{d} ; \mathrm{B}_{12}\right.$ crystalline powder $1 \%$ dilution), niacin $(3000 \mathrm{mg} / \mathrm{d}$; Rovimix niacin fine-crystalline powder 99.5\%), pantothenic acid (475 mg/d; Rovimix Calpan spray-dried 92\%), folic acid (100 mg/d; Rovimix Folic spray-dried $80 \%)$, and biotin $(20 \mathrm{mg} / \mathrm{d}$; Rovimix H-2 spray-dried $2 \%)$; BBVIT2X = supplemental thiamin (300 mg/d; Rovimix $\mathrm{B}_{1}$ fine-crystalline powder $\left.92 \%\right)$, riboflavin $\left(300 \mathrm{mg} / \mathrm{d}\right.$; Rovimix $\mathrm{B}_{2}$ spray-dried $\left.80 \%\right)$, pyridoxine $\left(240 \mathrm{mg} / \mathrm{d}\right.$; Rovimix $\mathrm{B}_{6}$ fine-crystalline powder $\left.82 \%\right), \mathrm{B}_{12}\left(1.0 \mathrm{mg} / \mathrm{d} ; \mathrm{B}_{12}\right.$ crystalline powder $1 \%$ dilution), niacin $(6000 \mathrm{mg} / \mathrm{d}$; Rovimix Niacin fine-crystalline powder $99.5 \%)$, pantothenic acid $(950 \mathrm{mg} / \mathrm{d}$; Rovimix Calpan spray-dried 92\%), folic acid (200 mg/d; Rovimix Folic spray-dried 80\%), and biotin (40 mg/ d; Rovimix H-2 spray-dried $2 \%$ ).

${ }^{2} \mathrm{~B} 1 \mathrm{X}=$ supplemental biotin at $20 \mathrm{mg} / \mathrm{d}$ (Rovimix $\mathrm{H}-2$ spray-dried $2 \%$ ); B2X = supplemental biotin at 40 $\mathrm{mg} / \mathrm{d}$ (Rovimix H-2 spray-dried 2\%); BBVIT1X = supplemental thiamin $\left(150 \mathrm{mg} / \mathrm{d}\right.$; Rovimix $\mathrm{B}_{1}$ fine-crystalline powder $92 \%$ ), riboflavin (150 mg/d; Rovimix $B_{2}$ spray-dried $\left.80 \%\right)$, pyridoxine $\left(120 \mathrm{mg} / \mathrm{d}\right.$; Rovimix $\mathrm{B}_{6}$ finecrystalline powder $82 \%), \mathrm{B}_{12}\left(0.5 \mathrm{mg} / \mathrm{d}\right.$; $\mathrm{B}_{12}$ crystalline powder $1 \%$ dilution), niacin $(3000 \mathrm{mg} / \mathrm{d}$; Rovimix niacin fine-crystalline powder 99.5\%), pantothenic acid (475 mg/d; Rovimix Calpan spray-dried 92\%), folic acid (100 mg/d; Rovimix Folic spray-dried 80\%), and biotin $(20 \mathrm{mg} / \mathrm{d}$; Rovimix H-2 spray-dried $2 \%)$.

no clear explanation for reduced lactation performance of cows fed BBVIT2X compared to cows fed B or BBVIT1X, which may have been related to lower DMI for BBVIT2X (24.4 vs. 25.0 to $25.7 \mathrm{~kg} / \mathrm{d})$. It is unclear why DMI was lower for BBVIT2X, but poor palatability and (or) negative interactions among the B-vitamins at the high dosages may have been factors.

Apparent total-tract DM, OM, and NDF digestibilities were not different across treatments $(P>0.10)$. This suggests that the observed intake differences were not related to changes in diet digestibility. Our data do not support the suggestion of Zimmerly and Weiss (2001) that biotin increases milk yield partially through improved fiber digestibility. Dietary biotin supplementation had no effect on ruminal VFA molar percentages in the trial of Zimmerly and Weiss (2001). Zimmerly and Weiss (2001) suggested that biotin increases milk yield partially through increased glucose production, because biotin is a cofactor for the glucogenic enzyme pyruvate carboxylase and for the enzyme propionylCoA carboxylase (McDowell, 2000). Plasma glucose, NEFA and BHBA concentrations were not different across treatments $(P>0.10)$. Similarly, dietary biotin supplementation had no effect on plasma glucose and
NEFA concentrations measured at $1,30,60$, and 100 DIM in the trial of Zimmerly and Weiss (2001). Plasma metabolite concentrations do not measure the amount of metabolite produced or utilized, and therefore may not be good indicators of treatment effects on nutrient metabolism.

Biotin efficacy in the short-term (100 d) continuous lactation trial of Zimmerly and Weiss (2001) and our short-term (28 d periods) Latin square trial suggests that biotin may improve milk yield directly via effects on intake, digestion, and (or) metabolism rather than only indirectly via improved hoof health (Midla, 1998). However, no measurement of hoof health was made in the present experiment. Zinn et al. (1987) measured duodenal flows of several B-vitamins, and reported extensive ruminal microbial degradation of supplemental $\mathrm{B}$-vitamins with the exception of biotin and $\mathrm{B}_{6}$, which largely escaped ruminal degradation. Their observations regarding microbial degradation may partially explain the variable responses to supplemental ruminally-unprotected B-vitamins reported in the literature including the lack of response to BBVIT1X over B in this study, and the more consistent positive efficacy reports for supplemental ruminally-unprotected biotin 
Table 4. Impact of dietary supplementation with Biotin and a B-vitamin blend on apparent total-tract nutrient digestion and plasma metabolites for Trial $1 .^{1}$

\begin{tabular}{lrrrrr}
\hline Item & C & B & BBVIT1X & BBVIT2X & SE \\
\hline Digestibility & & & & & \\
DM, \% & 64.5 & 63.8 & 64.6 & 65.5 & 1.2 \\
OM, \% & 68.9 & 67.6 & 69.0 & 70.6 & 1.4 \\
NDF, \% & 45.3 & 44.5 & 44.9 & 45.5 & 1.0 \\
Plasma Parameter & & & & & \\
Glucose, mg/dl & 60.4 & 60.8 & 61.0 & 113.6 & 0.9 \\
NEFA, $\mu$ Eq/ml & 109.6 & 111.8 & 113.4 & 7.2 & 0.0 \\
BHBA, mg/dl & 6.6 & 6.6 & 6.7 & \\
\hline
\end{tabular}

${ }^{1} \mathrm{C}=$ control diet with no supplemental B-vitamins; B = supplemental biotin at $20 \mathrm{mg} / \mathrm{d}$ (Rovimix H-2 spray-dried 2\%); BBVIT1X = supplemental thiamin $\left(150 \mathrm{mg} / \mathrm{d}\right.$; Rovimix $\mathrm{B}_{1}$ fine-crystalline powder $\left.92 \%\right)$, riboflavin ( $150 \mathrm{mg} / \mathrm{d}$; Rovimix $\mathrm{B}_{2}$ spray-dried $\left.80 \%\right)$, pyridoxine $\left(120 \mathrm{mg} / \mathrm{d}\right.$; Rovimix $\mathrm{B}_{6}$ fine-crystalline powder $82 \%), \mathrm{B}_{12}\left(0.5 \mathrm{mg} / \mathrm{d} ; \mathrm{B}_{12}\right.$ crystalline powder $1 \%$ dilution), niacin $(3000 \mathrm{mg} / \mathrm{d}$; Rovimix niacin fine-crystalline powder 99.5\%), pantothenic acid (475 mg/d; Rovimix Calpan spray-dried 92\%), folic acid (100 mg/d; Rovimix Folic spray-dried $80 \%$ ), and biotin (20 mg/d; Rovimix H-2 spray-dried $2 \%$ ); BBVIT2X = supplemental thiamin $\left(300 \mathrm{mg} / \mathrm{d}\right.$; Rovimix $\mathrm{B}_{1}$ fine-crystalline powder $\left.92 \%\right)$, riboflavin $\left(300 \mathrm{mg} / \mathrm{d}\right.$; Rovimix $\mathrm{B}_{2}$ spray-dried $\left.80 \%\right)$, pyridoxine $\left(240 \mathrm{mg} / \mathrm{d}\right.$; Rovimix $\mathrm{B}_{6}$ fine-crystalline powder $\left.82 \%\right), \mathrm{B}_{12}\left(1.0 \mathrm{mg} / \mathrm{d} ; \mathrm{B}_{12}\right.$ crystalline powder $1 \%$ dilution), niacin $(6000 \mathrm{mg} / \mathrm{d}$; Rovimix Niacin fine-crystalline powder $99.5 \%)$, pantothenic acid $(950 \mathrm{mg} / \mathrm{d}$; Rovimix Calpan spray-dried 92\%), folic acid (200 mg/d; Rovimix Folic spray-dried 80\%), and biotin (40 mg/ d; Rovimix H-2 spray-dried 2\%).

including the response to $\mathrm{B}$ over $\mathrm{C}$ in this study. Richards et al. (2002) reported that milk yield was increased $3.7 \mathrm{~kg} / \mathrm{d}$ above control (no supplemental B-vitamins) by a B-vitamin blend (rumen protected choline, niacin, $\mathrm{B}_{12}$, biotin, folic acid, and thiamin) during the first 90 DIM, but the composition of the blend was not provided because a proprietary product was being evaluated. Stage of lactation may have affected the response to B-vitamins in our trial. Extensive microbial degradation of some supplemental B-vitamins suggests a possible role for ruminally-protected B-vitamins to improve efficacy, consistency of response, and (or) reduce minimum effective dosages of B-vitamin blends, but more research on duodenal flows and animal requirements for the various B-vitamins is needed to improve supplement development. Based on positive efficacy reported for biotin in our study and the studies of Margerison et al. (2002), Midla et al. (1998), and Zimmerly and Weiss (2001), it does not appear that biotin is a B-vitamin that requires ruminal protection.

\section{Trial 2}

Body weight, DMI, and milk yield were not different $(P>0.10)$ among the treatments and averaged 674, 25.8 , and $41.0 \mathrm{~kg} / \mathrm{d}$, respectively. Feed efficiency $(\mathrm{kg}$ milk/kg DMI $)$ was similar $(P>0.10)$ across treatments and averaged 1.61 (data not presented in table). Milk composition and component yields were not different $(P>0.10)$ among the treatments. The $40 \mathrm{mg} / \mathrm{d}$ biotin treatment (B2X) or the B-vitamin blend (BBVIT1X) did not enhance lactation performance over the $20 \mathrm{mg} / \mathrm{d}$ biotin treatment (B1X). Although, Kluenter et al. (1993) reported linear increases in plasma and milk biotin concentrations with increasing incremental intakes of oral supplemental biotin from 0 to $80 \mathrm{mg} / \mathrm{d}$.

\section{CONCLUSIONS}

In Trial 1, DMI and milk yield were 0.7 and $1.7 \mathrm{~kg} /$ $\mathrm{d}$, respectively, higher for cows supplemented with 20 mg/d dietary biotin compared to control cows. There was no further benefit to supplementing a B-vitamin blend along with biotin. In Trial 2, there was no benefit to dietary supplementation with $40 \mathrm{mg} / \mathrm{d}$ biotin or the B-vitamin blend over $20 \mathrm{mg} / \mathrm{d}$ supplemental dietary biotin. Conclusions regarding the B-vitamin blend should not be interpreted too broadly, because duodenal flows and animal requirements for the various B-vitamins are not well defined and a blend with a different B-vitamin composition or fed earlier in lactation may elicit a different response. Income minus feed cost is expected to increase $\$ 0.20 / \mathrm{d}$ per cow from dietary biotin supplementation assuming a $1.7 \mathrm{~kg} / \mathrm{d}$ increase in milk yield at a milk price of $\$ 0.26 / \mathrm{kg}, \$ 0.15 / \mathrm{d}$ cost for $20 \mathrm{mg} /$ $\mathrm{d}$ supplemental biotin, and a $0.7 \mathrm{~kg} / \mathrm{d}$ increase in DMI at a ration cost of $\$ 0.15 / \mathrm{kg}$ DM. More research is needed to determine the mode of action for supplemental dietary biotin.

\section{REFERENCES}

Association of Official Analytical Chemists. 1997. Official Methods of Analysis. 16th ed. AOAC Intl., Gaithersburg, MD.

Erdman, R. A. 1994. Production responses in field study herds fed rumen protected choline. J. Dairy Sci. 77:(Suppl. 1)186(Abstr.).

Girard, C. L., and J. J. Matte. 1997. Parenteral supplements of vitamin B12 and milk performance of dairy cows. J. Dairy Sci. 80:(Suppl. 1)240(Abstr.). 
Girard, C. L., and J. J. Matte. 1998. Dietary supplements of folic acid during lactation: Effects on the performance of dairy cows. J. Dairy Sci. 81:1412-1419.

Hayirli, A., S. J. Bertics, and R.R. Grummer. 2002. Effects of slowrelease insulin on production, liver triglyceride, and metabolic profiles of Holsteins in early lactation. J. Dairy Sci. 85:2180-2191.

Kluenter, A. M., W. Steinberg, and W. Schueep. 1993. Influence of biotin supplementation on the concentration of biotin in the blood plasma and milk of dairy cows. Roche Res. Rep. B-162'112.

Margerison, J. K., B. Winkler, and B. Penny. 2002. The effect of supplementary biotin on milk production in Holstein cows. Page 219 in Proc. XXII World Buiatrics Congress. Hannover, Germany.

McDowell L. R. 2000. Vitamins in animal and human nutrition. 2nd Ed. Iowa State Univ. Press, Ames.

Midla, L. T., K. H. Hoblet, W. P. Weiss, and M. L. Moeschberger. 1998. Supplemental dietary biotin for prevention of lesions associated with aseptic subclinical laminitis (pododermatitis aseptica diffusa) in primiparous cows. Am. J. Vet. Res. 59:733-738.

National Research Council. 1988. Nutrient requirements of swine. 9th rev. ed. Natl. Acad. Sci., Washington D.C.

National Research Council. 2001. Nutrient requirements of dairy cattle. 7th rev. ed. Natl. Acad. Sci., Washington D.C.

Richards, S. E., S. Hicklin, T. Lord, A. Nickson, J. Long, J. Brackenbury, and J. R. Newbold. 2002. Effects of B vitamins and methyl group donors on milk production, milk composition and blood chemistry in dairy cows. Page 196 in Proc. Brit. Soc. Anim. Sci. Annu. Mtg. York, UK.

Roche Vitamin Nutrition Compendium. 2000. Roche Vitamins, Inc. Parsippany, NJ. RCD 9988.

SAS/STAT. 1999. User's guide, version 8.0. SAS Inst., Inc., Cary, NC.

Sharma, B. K., and R. A. Erdman. 1988. Effects of high amounts of dietary choline supplementation on duodenal choline flow and production responses of dairy cows. J. Dairy Sci. 71:2670-2676.

Shaver, R. D. and M. A. Bal. 2000. Effect of dietary thiamin supplementation on milk production by dairy cows. J. Dairy Sci. 83:2335-2340.

Shurson, J., T. Salzer, and D. Koehler. 1996. Effect of metal specific amino acid complexes and inorganic trace minerals on vitamin stability in premixes. Pages 235-261 in Proc. 57th MN Nutr. Conf. Bloomington, MN.

Van Soest, P. J., J. B. Robertson, and B. A. Lewis. 1991. Methods for dietary fiber, neutral detergent fiber, and non-starch polysaccharides in relation to animal nutrition. J. Dairy Sci. 74:35833597.

Zimmerly C. A. and W. P. Weiss. 2001. Effects of supplemental dietary biotin on performance of Holstein cows during early lactation. J. Dairy Sci. 84:498-506.

Zinn, R. A., F. N. Owens, R. L. Stuart, J. R. Dunbar and B. B. Norman. 1987. B-vitamin supplementation of diets for feedlot calves. J. Anim. Sci. 65:267-277. 